\title{
Analisis Mutu Organoleptik dan Kadar Air Ikan Roa (Hemiramphus sp.) Asap dengan Metode Pengasapan Berbeda
}

\section{(Analysis of Organoleptic Quality and Water Content of Smoked Roa Fish (Hemiramphus sp.) with Different Methods of Smoking)}

\author{
Rosdiani Azis*, Ingka Rizkyani Akolo \\ (Diterima Agustus 2019/Disetujui Mei 2020)
}

\begin{abstract}
ABSTRAK
Ikan merupakan salah satu sumber protein tinggi dan termasuk komoditas yang mudah mengalami pembusukan. Salah satu metode untuk menghambat proses pembusukan pada ikan adalah pengasapan. Salah satu ikan asap yang sering dikonsumsi masyarakat Gorontalo adalah ikan roa (Hemiramphus sp.) asap. Ikan roa asap diolah dengan cara tradisional melalui pembakaran dengan kayu sebagai bahan bakarnya. Pengolahan ikan secara sederhana memiliki beberapa kekurangan, yaitu aspek sanitasi yang kurang terjaga pada proses pengolahan. Dalam upaya memperbaiki produk olahan tradisional khas Gorontalo, yakni ikan roa asap, dilakukan terobosan baru dalam pembuatan ikan roa asap dengan menggunakan metode asap cair. Asap cair mengandung senyawa fenol dan asam organik yang bersifat sebagai senyawa antibakteri dan antioksidan. Tujuan penelitian ini adalah untuk menentukan pengaruh penggunaan metode pengasapan berbeda pada mutu organoleptik (kenampakan, aroma, rasa, dan tekstur) dan kadar air ikan roa asap. Metode pengasapan yang digunakan adalah pengasapan asap cair dan pengasapan tradisional. Penelitian ini menggunakan dua perlakuan, masing-masing dengan 3 ulangan. Perlakuan yang digunakan ialah metode pengasapan asap cair dan metode pengasapan tradisional. Hasil penelitian menunjukkan bahwa ikan roa asap cair lebih disukai panelis, dibandingkan ikan roa asap tradisional. Ikan roa asap cair memiliki kenampakan yang cerah, warna asap tersebar merata (seragam), aroma asap lembut, rasa ikan lezat, dan teksturnya keras, berbeda dari ikan roa asap tradisional yang kenampakannya cenderung kusam, warna asap tidak merata, dan rasa asap pada ikan juga cukup tajam. Ikan roa asap cair juga memiliki kadar air yang lebih kecil dibandingkan dengan ikan roa asap tradisional. Uji statistik menunjukkan bahwa metode pengasapan berpengaruh nyata pada aroma dan kadar air ikan roa asap.
\end{abstract}

Kata kunci: asap cair, ikan roa, ikan roa asap, organoleptik, pengasapan tradisional

\section{ABSTRACT}

Fish is one source of high protein and included a commodity which is easily to decay. The way to inhibit the decay process of fish is fumigation. One of the smoked fishes that is often consumed by Gorontalo people is smoked Roa fish (Hemiramphus sp.). Smoked Roa fish is processed with traditional way through burning using woods as the fuel. Simply or conventionally fish processing like that has several flaws such as less protected of the sanitation aspects in the processing protocol. In order to improve the traditional processed product of Gorontalo, that is a smoked Roa fish, a new breakthrough in making smoked Roa fish was made by using the liquid smoke method. Liquid smoke contains compound of phenol and organic acids that are antibacterial and antioxidant compounds. The purpose of this research is to evaluate the effect of using different fumigation methods on organoleptic quality (appearance, smell, taste, and texture) of smoked Roa fish. The fumigation methods used were fumigation with liquid smoke and fumigation with traditional method. This research used a completely randomized design with 2 treatments and 3 times of replications. The results showed that liquid smoked Roa fish were preferred by panelists, compared to traditional smoked Roa fish. Liquid smoked Roa fish had a bright appearance, the smoke color was spread evenly (uniform), the smell of soft smoke, delicious fish taste, and hard texture that were different from traditional smoked Roa fish which appearance tended to be dull, the color of the smoke was not evenly distributed, the smoke taste in the fish was also quite sharp. Liquid smoked Roa fish also had a lower water content than traditional smoked Roa fish. Statistical tests showed that the fumigation method had a significant effect on the smell and water content of smoked Roa fish.

Keywords: hedonics, liquid smoke, organoleptic, Roa fish, traditional fumigation

Program Studi Teknologi Hasil Pertanian, Politeknik Gorontalo, JI. Muchlis Rahim, Desa. Panggulo Barat, Kec. Botupingge, Bone Bolango, Gorontalo 96551

*Penulis Korespondensi: Email: rosdiani@poligon.ac.id

\section{PENDAHULUAN}

Ikan merupakan salah satu sumber protein yang sangat dibutuhkan manusia. Kandungan protein dan air yang terdapat pada ikan cukup tinggi sehingga ikan 
termasuk komoditas yang mudah mengalami pembusukan (Patty et al. 2015). Salah satu cara untuk menghambat proses pembusukan pada ikan adalah pengasapan. Pengasapan merupakan suatu cara pengolahan atau pengawetan dengan memanfaatkan kombinasi perlakuan pengeringan dan pemberian senyawa kimia dari hasil pembakaran bahan bakar alami (Wibowo 2000). Menurut Adawyah (2008), pengasapan juga dapat berfungsi untuk menambah cita rasa dan warna pada makanan serta bertindak sebagai antibakteri dan antioksidan.

Salah satu komoditas potensial yang ada di Gorontalo adalah ikan roa atau julung-julung (Hemiramphus sp.). Ikan roa oleh masyarakat Gorontalo diolah dengan cara pengasapan untuk memperpanjang masa simpannya. Ikan roa asap (nama tradisionalnya adalah Sagela) merupakan satu produk olahan yang banyak dikonsumsi masyarakat dan diolah dengan cara tradisional, yakni pengasapan panas dengan suhu $65-80^{\circ} \mathrm{C}$ dengan kayu sebagai bahan bakarnya. Cara pengasapan seperti ini sudah dilakukan secara turun temurun di Gorontalo dan Sulawesi Utara (Patty et al. 2015).

Penggunaan cara tradisional dalam proses pengasapan ikan disebabkan karena masyarakat belum mempertimbangkan aspek kesehatan dan keamanan pangan. Padahal, jika diperhatikan dengan saksama, ternyata pengasapan tradisional sering kali memberikan dampak negatif pada lingkungan serta timbul kekhawatiran konsumen atas senyawa karsinogenik yang berdampak buruk pada kesehatan (Swastawati et al. 2013). Oleh karena itu, diperlukan metode pengasapan yang modern dan mudah digunakan oleh masyarakat.

Beberapa tahun terakhir, sudah dikembangkan pengasapan dengan asap cair (liquid smoke). Pengasapan menggunakan asap cair, menurut Swastawati et al. (2014), dapat menghasilkan produk yang seragam, rasa yang ditimbulkan dapat dikontrol, memberikan cita rasa dan aroma yang konsisten, menghemat kayu, mengurangi polusi, dan mencegah deposit senyawa tar. Peran asap cair dalam industri pangan adalah sebagai pengawet (food preservative), khususnya sebagai antimikrob pangan (antimicrobial agent) dan pemberi cita rasa dan aroma pada produk makanan (flavouring agent). Aplikasi asap cair pada berbagai tujuan tersebut relatif lebih aman dibandingkan dengan penggunaan bahan tambahan pangan lainnya (Syahraeni et al. 2014).

Karakteristik sensoris ikan asap akan bergantung pada beberapa faktor, seperti perbedaan jenis bahan baku, jenis bahan bakar, metode pengasapan, jenis alat, dan kondisi pengasapan yang digunakan. Ada juga produk ikan asap yang sebenarnya sama, tetapi dikenal dengan nama berbeda di daerah lain. Masingmasing daerah produsen biasanya memiliki ciri khas dalam pengolahan ikan asap ini sehingga karakteristik sensoris produk akhirnya pun akan berbeda (Pratama et al. 2012).
Oleh karena itu, ikan roa asap merupakan makanan khas Gorontalo yang sering dikonsumsi dan dapat menjadi potensi pendapatan bagi masyarakat. Dengan demikian, diperlukan penelitian lebih lanjut tentang metode pengasapan yang terbaik sehingga dapat menghasilkan ikan roa asap yang bermutu bagus dan dapat diterima di masyarakat. Tujuan penelitian ini adalah untuk menentukan pengaruh penggunaan metode pengasapan berbeda pada mutu organoleptik (atribut kenampakan, aroma, rasa, dan tekstur) dan kadar air ikan roa asap.

\section{METODE PENELITIAN}

\section{Bahan dan Alat}

Bahan dan alat yang digunakan dalam penelitian ini adalah ikan roa segar, asap cair, tempurung kelapa, aluminium foil, bambu untuk menjepit ikan roa, tungku pengasapan, pisau, talenan, wadah, kertas label, tissue roll, aquadest, desikator, timbangan analitik, thermometer, stopwatch, pisau, gelas ukur, pipet mikro, dan pipet tetes.

\section{Metode Penelitian}

Penelitian ini dilaksanakan di Laboratorium Teknologi Hasil pertanian, Politeknik Gorontalo pada bulan Mei-Juli 2019. Penelitian terdiri atas dua tahap, yakni 1) Pembuatan ikan roa asap dengan metode pengasapan berbeda dan 2) Pengujian kadar air dan organoleptik (atribut kenampakan, aroma, rasa, dan tekstur) ikan roa asap. Penelitian menggunakan faktor tunggal, yakni dua me-tode pengasapan, yaitu metode pengasapan dengan asap cair dan metode pengasapan tradisional.

\section{Prosedur Pembuatan Ikan Roa Asap dengan Metode Asap Cair (Modifikasi Katiandagho et al. 2017)}

Bahan baku utama adalah ikan roa. Langkah awal adalah ikan roa dibersihkan isi perutnya (sisik tidak dikeluarkan). Setelah dibersihkan, ikan kemudian ditimbang menggunakan timbangan digital. Selanjutnya, ikan direndam selama 5 menit dengan air garam konsentrasi 5\% (dari bobot ikan). Setelah direndam dengan air garam, ikan direndam dengan asap cair konsentrasi 3\% dengan lama perendaman 30 menit. Selanjutnya, ikan dikeringkan dalam oven pengering selama 6 jam pada temperature $130^{\circ} \mathrm{C}$. Setelah matang, ikan dikeluarkan dari oven dan didinginkan (Katiandagho et al. 2017).

\section{Prosedur Pembuatan Ikan Roa Asap dengan Metode Pengasapan Tradisional}

Bahan baku utama adalah ikan roa. Langkah awal adalah ikan roa dibersihkan isi perutnya (sisik tidak dikeluarkan). Setelah dibersihkan, ikan kemudian ditimbang menggunakan timbangan digital. Selanjutnya, ikan direndam selama 5 menit dengan air garam 
konsentrasi 5\% (dari bobot ikan). Setelah direndam dengan air garam, ikan ditusuk dengan kawat dan digantung pada belahan bambu yang dipasang secara teratur dalam tungku pengasapan. Kayu/batok kelapa yang merupakan sumber asap sebelumnya dibakar di luar. Setelah menjadi bara kemudian dimasukkan ke dalam tungku pengasapan bagian bawah. Kemudian, ditambahkan lagi tempurung kelapa untuk mendapatkan asap yang lebih banyak. Ikan diasapi selama \pm 6 jam (Swastawati et al. 2013).

\section{Prosedur Analisis Kadar Air Metode Gravimetri (AOAC 2005)}

Sampel sebanyak $1 \mathrm{~g}$ ditimbang dalam cawan. Selanjutnya dimasukkan ke dalam oven dengan suhu $130^{\circ} \mathrm{C}$ selama 8 jam, lalu ditimbang sampel untuk menentukan kadar airnya. Rumus yang digunakan untuk penghitungan kadar air adalah:

$$
\text { Kadar air (\%) }=\frac{\text { bobot sampel }(\text { segar }- \text { kering) }}{\text { bobot sampel segar }} \times 100 \%
$$

\section{Prosedur Uji Organoleptik}

Analisis sensoris dilakukan pada empat kriteria mutu, yaitu, rasa, warna, aroma, dan tekstur. Uji yang digunakan adalah uji rating hedonic berdasarkan SNI. Kategori panelis dalam penelitian ini adalah masyarakat yang sudah sering mengonsumsi ikan roa asap dengan rentang umur 19-64 tahun dan mempunyai pekerjaan yang berbeda-beda. Panelis yang digunakan adalah panelis tidak terlatih dengan jumlah 30 orang. Pada penelitian ini digunakan 9 skala hedonik dengan urutan skala 1-9, di mana skala 1 menyatakan sangat tidak suka, dan skala 9 menyatakan sangat suka.

\section{HASIL DAN PEMBAHASAN}

\section{Organoleptik Kenampakan}

Pada Gambar 1 ditunjukkan bahwa ikan roa asap dengan metode asap cair mempunyai permukaan mutu ikan asap cerah, cemerlang, ikan berwarna cokelat kekuningan, serta permukaan ikan yang terkena asap tersebar merata. Hal ini disebabkan karena jenis asap yang digunakan pada ikan roa asap cair memiliki warna yang bening, jernih, dan alat pengasapan menggunakan oven dengan suhu $130^{\circ} \mathrm{C}$ sehingga lebih merata dibandingkan dengan asap tradisional, sedangkan ikan roa asap dengan metode pengasapan tradisional berwarna cokelat agak gelap, permukaan ikannya lebih kusam, serta warna permukaan ikan sebagian cerah sebagian lagi agak gelap. Keadaan ini mengindikasikan bahwa warna permukaan ikan roa asap dengan metode tradisional tidak seragam karena jenis asap pembakaran yang digunakan lebih hitam dan media pengasapan pun suhunya tidak merata. Selain itu, ikan roa asap yang diolah dengan kedua metode pengasapan ini tidak tampak adanya kotoran berupa darah yang mengering, sisa isi perut, abu, atau kotoran lainnya, serta tidak tampak adanya jamur sehingga memenuhi kriteria mutu sensoris untuk atribut kenampakan ikan asap (Sulistijowati et al. 2011). Menurut penelitian yang dilakukan Suroso et al. (2018) pada pengasapan ikan kembung menggunakan asap cair dari kayu karet hasil redestilasi menunjukkan bahwa daya terima panelis terhadap sifat organoleptik pada ikan asap secara umum menjadi lebih tinggi karena selama pengovenan produk akan menjadi lebih awet, warna, aroma, dan rasa menjadi lebih baik. Hal ini disebabkan oleh adanya reaksi kimia persenyawaan dalam asap antara formaldehida dengan fenol yang menghasilkan lapisan dammar tiruan pada permukaan kulit ikan. Dari segi kenampakan produk, ada yang sebagian tampak hangus (terlalu merah kecokelatan).

Pada Gambar 2 ditunjukkan bahwa kenampakan ikan roa asap dengan asap cair lebih disukai panelis dibandingkan ikan roa asap tradisional. Hal ini disebabkan karena suhu yang digunakan pada metode asap cair lebih terkontrol dan prosesnya lebih higienis sehingga kenampakannya lebih seragam dan lebih disukai dibandingkan ikan roa asap metode tradisional.

Nilai rata-rata uji hedonik untuk kenampakan ikan roa asap dengan asap cair juga sudah memenuhi standar SNI ikan asap, yakni 7,40, sedangkan ikan roa asap dengan metode tradisional belum memenuhi standar SNI karena nilainya masih di bawah 7 . Berdasarkan uji Friedman diperoleh bahwa metode pengasapan ternyata tidak berpengaruh nyata pada kenampakan ikan roa asap, di mana diperoleh nilai $p$ value $>5 \%$. Hal ini berarti bahwa secara statistik metode pengasapan tidak berpengaruh signifikan pada kenampakan ikan roa asap. Akan tetapi, secara deskriptif ikan roa asap cair lebih disukai oleh panelis dibandingkan ikan roa asap tradisional.

\section{Organoleptik Aroma}

Pada Gambar 3 ditunjukkan bahwa aroma ikan roa asap dengan asap cair lebih disukai panelis dibandingkan dengan ikan roa asap tradisional. Hal ini

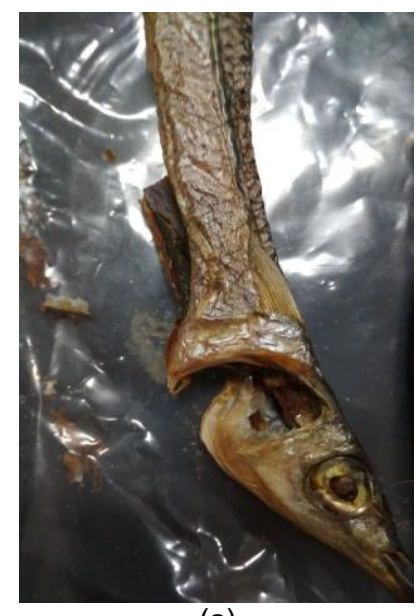

(a)

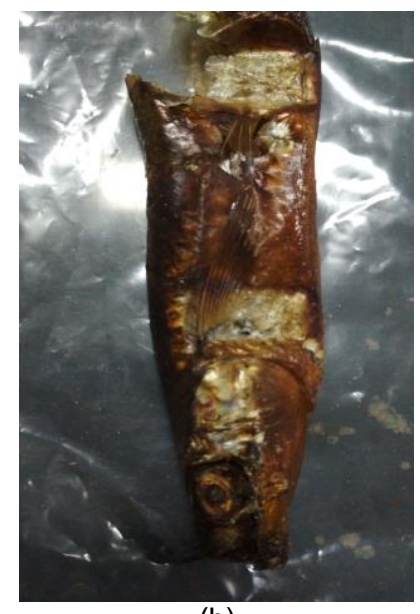

(b)
Gambar 1 a) Ikan roa asap cair dan b) Ikan roa asap tradisional. 
disebabkan karena aroma asap ikan roa asap dengan asap cair cukup lembut, sedangkan aroma ikan roa asap tradisional cukup tajam. Selain itu, kedua ikan ini tidak memiliki bau tengik, tanpa bau apek dan bau busuk. Adanya perbedaan aroma dikarenakan aroma asap cair lebih lembut dan tidak menusuk, sedangkan untuk asap pembakaran tradisional lebih tajam karena adanya pembakaran yang lama sehingga berpengaruh pada produk yang dihasilkan.

Dari hasil uji hedonik diperoleh bahwa nilai rata-rata tingkat kesukaan panelis terhadap aroma ikan asap cair yang memenuhi standar SNI adalah aroma ikan roa asap cair, yakni 7,17 , sedangkan nilai rata-rata tingkat kesukaan panelis untuk aroma ikan asap tradisional masih di bawah standar, yakni 5,90. Hal ini menandakan bahwa meskipun produk ikan roa asap tradisional sudah sering dikonsumsi oleh masyarakat, aroma ikan roa asap tradisional ternyata belum memenuhi standar SNI ikan asap. Berdasarkan uji Friedman diperoleh bahwa metode pengasapan ternyata memberikan pengaruh nyata pada aroma ikan roa asap, di mana diperoleh nilai $p$-value $<5 \%$.

\section{Organoleptik Rasa}

Pada Gambar 4 ditunjukkan bahwa rasa ikan roa asap dengan asap cair lebih disukai panelis dibandingkan ikan roa asap tradisional. Meskipun keduanya sama-sama lezat dan enak, tidak pahit dan tidak tengik, ikan roa asap cair mempunyai rasa asap yang lebih lembut dibandingkan ikan roa asap tradisional. Kandungan asap cair dan asap pembakaran sangat

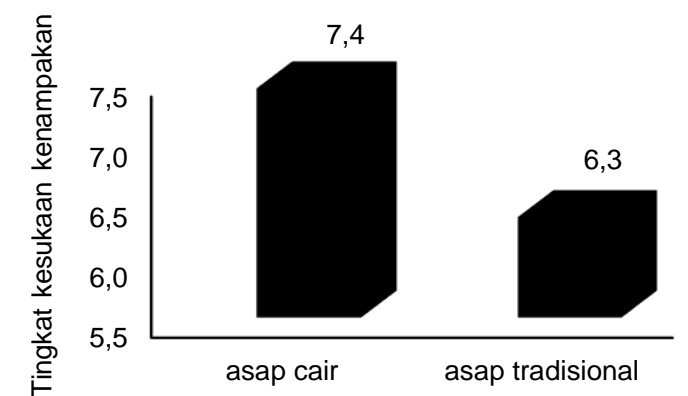

Gambar 2 Tingkat kesukaan asap cair dan asap tradisional (skala 1-9) dengan uji hedonik atribut kenampakan.

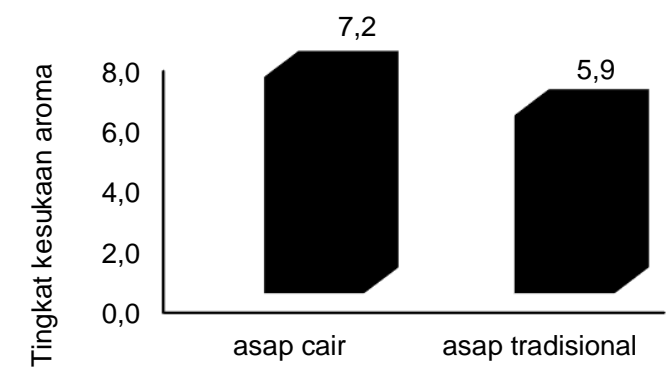

Gambar 3 Tingkat kesukaan aroma asap cair dan asap tradisional (skala 1-9) uji hedonik atribut warna. berpengaruh pada rasa produk yang diaplikasikan dengan asap tersebut.

Dari hasil uji hedonik diketahui bahwa nilai rata-rata tingkat kesukaan panelis terhadap rasa ikan roa asap yang diproses dengan kedua metode ini sama-sama memenuhi standar SNI, yakni di atas nilai 7 . Berdasarkan uji Friedman diperoleh bahwa metode pengasapan tidak berpengaruh pada rasa ikan roa asap, di mana nilai $\mathrm{p}$-value $>5 \%$.

\section{Organoleptik Tekstur}

Pada Gambar 5 ditunjukkan bahwa tekstur ikan roa asap dengan asap cair lebih disukai panelis dibandingkan dengan ikan roa asap tradisional. Meskipun keduanya sama-sama tidak lembek, teksturnya kompak dan tidak mudah rapuh, ternyata panelis lebih menyukai ikan roa asap cair karena teksturnya lebih keras dibandingkan ikan roa asap tradisional sehingga mudah untuk diolah menjadi olahan sambal roa khas Gorontalo. Tekstur yang berbeda ini dihasilkan dari perbedaan suhu pembakaran dan media pembakaran ikan asap cair yang memiliki suhu merata dengan media oven, sedangkan ikan asap tradisional dihasilkan dari suhu yang tidak merata dan media pembakaran dengan pengasapan di atas kayu yang telah dibakar.

Dari hasil uji hedonik diketahui bahwa nilai rata-rata tingkat kesukaan panelis terhadap rasa ikan roa asap yang diproses dengan kedua metode ini sama-sama memenuhi standar SNI, yakni di atas nilai 7 . Berdasarkan uji Friedman diperoleh bahwa metode

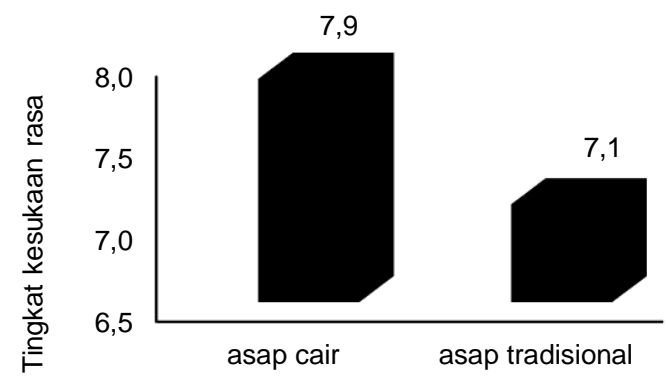

Gambar 4 Tingkat kesukaan rasa asap cair dan asap tradisional (skala 1-9) dengan uji hedonik atribut rasa.

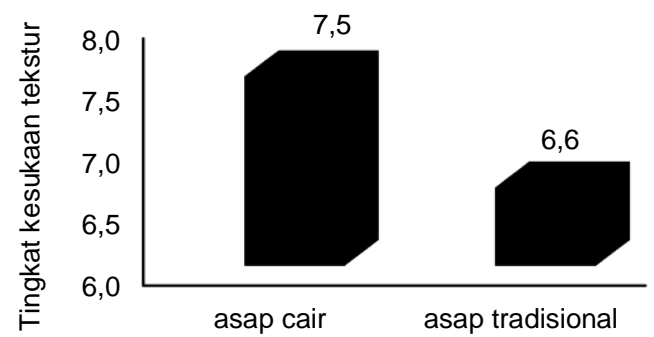

Gambar 5 Tingkat kesukaan tekstur asap cair dan asap tradisional (skala 1-9) uji hedonik atribut tekstur. 
pengasapan tidak berpengaruh pada rasa ikan roa asap, d i mana nilai $p$-value $>5 \%$.

\section{Analisis Kadar Air}

Air merupakan komponen penting dalam bahan pangan karena dapat memengaruhi tekstur, kenampakan, dan cita rasa makanan. Kadar air mempunyai peran penting dalam menentukan daya simpan bahan pangan karena dapat memengaruhi sifat fisik, perubahan-perubahan kimia, perubahan mikrobiologis, dan perubahan enzimatis (Winarno 2002).

Berdasarkan data pada Gambar 6 diketahui bahwa kadar air ikan roa asap cair lebih rendah dibandingkan dengan ikan roa asap tradisional. Hal ini menunjukkan bahwa ikan roa asap cair akan mempunyai daya simpan yang lebih lama dibandingkan dengan ikan roa asap tradisional. Perbedaan kadar air ini disebabkan oleh adanya perbedaan suhu pengeringan, yakni pada ikan roa dengan metode pengasapan asap cair suhu pengeringan yang digunakan adalah $130^{\circ} \mathrm{C}$ dengan media oven, dan waktu yang digunakan 6 jam, sementara untuk ikan roa tradisional tidak memiliki suhu pengeringan yang stabil karena dilakukan pembakaran ikan di atas asap yang tidak terdeteksi suhunya. Dengan demikian, hal ini berpengaruh pada kadar air yang dihasilkan, yang diasumsikan bahwa ikan roa asap cair memiliki suhu pengeringan yang lebih tinggi sehingga kadar air yang dihasilkan lebih rendah. Hal ini sesuai dengan pendapat Leiwakabessy \& Wenno (2019) yang mengatakan bahwa pengeringan digunakan untuk menghilangkan atau mengurangi sebagian air dari bahan pangan. Pengeringan menggunakan energi panas menyebabkan inaktivasi mikroorganisme penyebab pembusukan sehingga bahan yang dikeringkan dapat disimpan lebih lama. Hal ini sesuai dengan hasil uji lanjut penelitian Setha (2011) yang menunjukkan bahwa semakin lama perendaman ikan di dalam asap cair maka kadar air akan semakin rendah karena kadar air daging ikan yang direndam dalam larutan asap cair akan mengalami penurunan akibat proses osmosis. Jumlah air bebas yang terdapat dalam daging ikan akan semakin berkurang akibat masuknya komponen asap. Kadar air ikan roa asap ini juga masih memenuhi

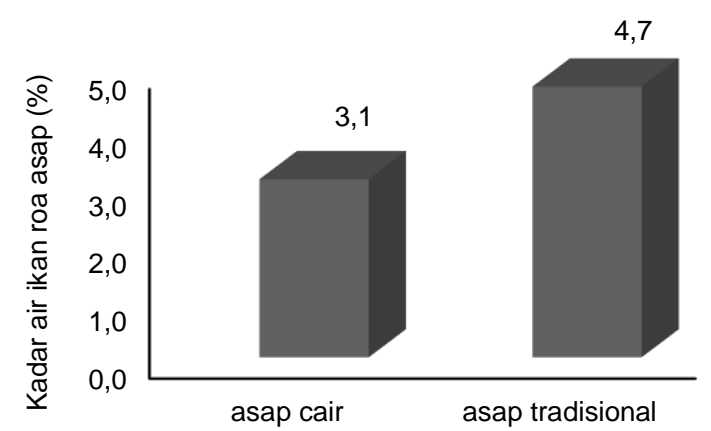

Gambar 6 Kadar air ikan roa asap dengan pengasapan asap cair dan asap tradisional. standar SNI ikan asap, yakni kadar air maksimal ikan asap adalah $60 \%$. Hasil analisis sidik ragam menunjukkan bahwa metode pengasapan berpengaruh nyata pada kadar air ikan roa asap, di mana diperoleh nilai $p$ value $<5 \%$.

\section{KESIMPULAN}

Secara deskriptif ada perbedaan mutu organoleptik ikan roa asap cair dan ikan roa asap tradisional. Ikan roa asap cair memiliki kenampakan yang cerah, cemerlang, warna asap tersebar merata (seragam), aroma asap lembut, rasa ikan lezat, dan teksturnya keras, berbeda dari ikan roa asap tradisional yang kenampakannya cenderung kusam, warna asap tidak tersebar merata, dan rasa asap pada ikan roa juga cukup tajam. Ikan roa asap juga memiliki kadar air yang lebih kecil dibandingkan dengan ikan roa asap tradisional. Berdasarkan pengujian diperoleh bahwa metode pengasapan hanya berpengaruh nyata pada aroma ikan asap dan kadar airnya. Ikan roa asap cair juga lebih disukai panelis dibandingkan ikan roa asap tradisional.

\section{UCAPAN TERIMA KASIH}

Ucapan terima kasih penulis berikan kepada Direktorat Riset dan Pengabdian Masyarakat, Direktorat Jenderal Penguatan Riset dan Pengembangan, Kementerian Riset, Teknologi, dan Pendidikan Tinggi, yang telah membiayai penelitian ini sesuai dengan Kontrak Penelitian Tahun Anggaran 2019.

\section{DAFTAR PUSTAKA}

[AOAC] Association of Official Analytical Chemists. 2005. Official Methods of Analysis. Washington (US): Benjamin Franklin Station.

Adawyah, R. 2008. Pengolahan dan Pengawetan lkan. Bumi Aksara. Jakarta

Katiandagho Y, Siegfried B, Albert RR. 2017. Pengaruh Konsentrasi Asap Cair dan Lama Perendaman terhadap Mutu Organoleptik Ikan Kayu (Katsuobushi). Jurnal Media Teknologi Hasil Perikanan. 5(1): 1-7. https://doi.org/10.35800/mthp.5. 1.2017 .14877

Leiwakabessy J, Wenno MR. 2019. Penambahan Asap Cair Mampu Mempertahankan Profil Asam Lemak Ikan Tuna Kering Blok. Jurnal Pengolahan Hasil Perikanan Indonesia. 22(3): 520-525. https:// doi.org/10.17844/jphpi.v22i3.29080

Patty NC, Dotulong V, Ketut IS. 2015. Mutu Ikan Roa (Hemirhamphus Sp.) Asap yang Ada di Pasar Tradisional di Kota Manado yang Disimpan pada Suhu Ruang. Jurnal Media Teknologi Hasil 
Perikanan. 3(2): 45-54. https://doi.org/10.35800/ mthp.3.2.2015.10354

Pratama RI, Sumaryanto HJ, Santoso, Zahirudin W. 2012. Karakteristik Sensori Beberapa Produk Ikan Asap Khas Daerah di Indonesia dengan Menggunakan Metode Quantitative Descrptive Analysis. Jurnal Pascapanen dan Bioteknologi Kelautan dan Perikanan. 2: 117-130. https:// doi.org/10.15578/jpbkp.v7i2.253

Setha, B. 2011. Pengaruh Penggunaan Asap Cair Terhadap Kualitas Fillet Ikan Cakalang Asap. Jurnal Ilmu Pengetahuan dan Teknologi. 9 (1): 28- 37.

Sulistijowati S, Otong R, Jetty N, Eddy A, Zalinar U. 2011. Mekanisme Pengasapan Ikan. Bandung (ID): Unpad Press.

Suroso E, Utomo TP, Hidayati S, Nuraini A. 2018. Pengasapan ikan kembung menggunakan asap cair dari kayu karet hasil redestilasi. Jurnal Pengolahan Hasil Perikanan Indonesia. 21(1): 42-53. https://doi.org/10.17844/jphpi.v21i1. 21261
Syahraeni K, Darmadji P, Hidayat C, Supriyadi. 2014. Sifat Fisikan dan Kimiawi Komponen Asap Cair Tempurung Kelapa Hasil Adsorpsi Pada Arang Aktif. Jurnal Agroland. 21(1): 7-14.

Swastawati F, Surti T, Agustini TW, Riyadi PH. 2013. Karakteristik Kualitas Ikan Asap yang Diproses Menggunakan Metode dan Jenis ikan Berbeda. Jurnal Aplikasi Teknologi Pangan. 2(3): 126-132. https://doi.org/10.17728/jatp.v2i3.142

Swastawati F, Megawati MT, Romadhon. 2014. Pengaruh Pengasapan dengan Variasi Konsentrasi Liquid Smoke Tempurung Kelapa yang Berbeda Terhadap Kualitas Ikan Bandeng (Chanos chanos Forsk) Asap. Jurnal Pengolahan dan Bioteknologi Hasil Perikanan. 3(4): 127-132

Wibowo S. 2000. Industri Pengasapan Ikan. Jakarta (ID): Penebar Swadaya.

Winarno. 2002. Kimia Pangan dan Gizi. Jakarta (ID): Gramedia Pustaka Utama. 